\title{
An Educational Interventional Study on Stem Cell Awareness among Eligible Beneficiaries in Central India
}

\author{
Priyesh Marskole ${ }^{1}$, Soumitra Sethia², Rashmi Yadav³, Sachin Parmar ${ }^{4}$ Leena Parihar 5 \\ 1,2,3,4, 5 Department of Community Medicine, Nandkumar Singh Chauhan Government Medical College, \\ Khandwa, Madhya Pradesh, India.
}

\section{ABSTRACT}

\section{BACKGROUND}

Stem cells are pluripotent cells that continuously divide, have the ability of selfrenewal, and can generate complex tissues and organs. Globally there are almost 20 lakh stem cell centres, whereas in India we don't have such a good network of stem cell registries. The Indian Council of Medical Research (ICMR) study says that if you have 10 lakh stem registries with you, you will be able to serve at least $40 \%$ of the demand, but when we have 20 lakh of the global registry we are not able to meet the demand because of genetic variation. We wanted to spread awareness on stem cells from various levels like NGO's, government, health sectors and everybody should take the initiative. The objective of the study was to assess knowledge and awareness of stem cells among eligible beneficiaries (ANC mothers and eligible couples)

\section{METHODS}

A cross-sectional educational interventional study was done in the Gwalior region for 2 months. A total of 100 eligible beneficiaries (ANC mothers and eligible couples) were registered for the study. Collection of questionnaire sheets \& sorting out of data for analysis was done.

\section{RESULTS}

After awareness, $86 \%$ of the subjects thought that the regenerated tissues from stem cells were good enough to replace the previous tissues and $91 \%$ of the subjects were willing to donate stem cells after awareness.

\section{CONCLUSIONS}

Doctors and health workers can be a potential source of information for these subjects because of effective convincing strategies.
Corresponding Author: Dr. Soumitra Sethia, Flat No. 204, Block-C, GMC Campus, Mundi Road, Khandwa-450001, Madhya Pradesh, India. E-mail: drsoumitrasethia@gmail.com

DOI: $10.14260 / \mathrm{jemds} / 2021 / 752$

How to Cite This Article:

Marskole P, Sethia S, Yadav R, et al. An educational interventional study on stem cell awareness among eligible beneficiaries in Central India. J Evolution Med Dent Sci 2021;10(43):3715-3719, 10.14260/jemds/2021/752

Submission 00-03-2021,

Peer Review 00-05-2021, Acceptance 00-06-2021, Published 25-10-2021.

Copyright (C) 2021 Priyesh Marskole et al. This is an open access article distributed under Creative Commons Attribution License [Attribution 4.0 International (CC BY 4.0)]

\section{KEY WORDS}

Stem Cells, Awareness, Umbilical Cord Blood (UCB). 


\section{BACKGROUND}

Stem cells are pluripotent cells that continuously divide, have the ability of self-renewal, and can generate complex tissues and organs. Stem cells are generally defined as clonogenic cells capable of both self-renewal and multi-lineage differentiation. ${ }^{1}$ Postnatal stem cells have been isolated from various tissues, including the umbilical cord, bone marrow, neural tissue, skin, retina, and dental epithelium. In general, there are two broad types of stem cells which are: embryonic stem cells and adult stem cells. Embryonic stem cells: They are found in the inner cell mass of the blastocyst during the early stages of embryo development. Their self-renewal potential and unrestricted ability to generate new tissues and organs (totipotency) make these cells an attractive cellular source for cell-based regenerative therapies. Adult stem cells: An adult stem cell is thought to be an undifferentiated cell, found among differentiated cells in a tissue or an organ. The adult stem cell can renew itself and can differentiate to yield some or all the major specialised cell types of the tissue or organ. The primary role of adult stem cells in a living organism is to maintain and repair the tissue in which they are found. History: The term stem cell was proposed for scientific use by Russian histologist Alexander Maksimov in 1908, while research on stem cells grew out of findings by Canadian scientists in the $1960 \mathrm{s.}^{2}$ Until recently, the cord blood that remains in the placenta and umbilical cord after birth were considered medical waste. In 1988, the first cord blood cell transplant took place to treat a child with Fanconi's Anaemia. Approximately, 6000 individuals worldwide have received medical treatment consisting of the infusion of human umbilical cord blood hematopoietic stem cells for the treatment of more than 70 life-threatening malignant and non-malignant diseases. ${ }^{3}$ As the newborn is delivered, and the umbilical cord is divided, blood can be collected from the segment of the cord still attached to the placenta. Stem cells retrieved from the blood in the remaining segment of the umbilical cord and placenta are known as 'umbilical cord blood (UCB) stem cells. This blood which is of no use to the mother or the baby and that has been treated as medical waste for centuries is a rich source of stem cells. UCB stem cells are unique and have many promising uses for the future. As these cells are naïve, on allogeneic transplantation, they produce an attenuated donor-derived immune response and thus have a lower incidence of graft-versus-host reaction when compared to other sources of stem cells (bone marrow or peripheral cells). ${ }^{4}$ Unlike other sources, these can also be transplanted even without an identical HLA match. The collection procedure is easy and without any risk to the donor (mother or baby). Unlike embryonic stem cells, these are not ethically controversial. Despite many advantages, UCB stem cells have certain limitations. It requires the appropriate collection, processing, and storage and a single UCB stem cell unit has remained a limiting factor for stem cell transplant in adult recipients. ${ }^{5}$ Likewise, a patient's UCB may not be useful in many cases as the precursor of the disease may be in the UCB stem cells as well. UCB can be banked in the following two ways: Private and Public UCB banks. Private Bankswherein the UCB of a newborn is stored at a certain cost. These UCB can be used only by the child or its family if a need arises. Public UCB banks-these are similar to blood banks. Here any pregnant woman can enrol to donate UCB at the time of childbirth free of cost, and anyone in need can utilise it at a certain cost.

India going strong with stem cell research: With the growing interest in the benefits of cord blood and stem cell in treating diseases, India is poised to be a major market for stem cell research in the years to come. With the growing interest in stem cell technology and its implications in saving lives, India is set to become a solid market for stem cell research. Parents who are advised by their doctors to enrol for cord blood banking, scientists and doctors working in regenerative medicine, the increasing numbers of people suffering from blood-related and autoimmune disorders...all of these are throwing the spotlight on stem cell research like never before. In the last decade, the stem cell research market has globally grown, while the investment in the sector in India was to the tune of $\$ 540$ million in the year $2010 .^{6}$ In his report "Stem Cell Entrepreneurship - Trends and Advances, Part II", Dr Winston Pareira wrote, "From just a few institutes in India two years back, today over 30 institutions are involved in stem cell research with the Indian government investing around $\$ 8$ million in just the last two years. What is the ultimate goal of Stem Cell research? Today, the ultimate aim of scientists is to be able to build tissues or organs that can replace injured or diseased tissues in the human body. This concept which gives rise to the generation of mature tissues has made adult stem cells the focus of intense research, designed to treat a variety of human diseases. In the clinical scenario, stem cells are expected to be transplanted into the damaged area and then grow into new, healthy tissue. $^{7}$ Considering the immense interest worldwide, it comes as no surprise that the global market for stem cell therapy was around $\$ 20$ billion in 2010 , as per the Frost \& Sullivan study. The growth of stem cell research in India was prompted by the interest of doctors associated with various disciplines such as cardiology, diabetology, spinal cord repair and ophthalmology, and who had several patients who had the potential to show improvement provided they received the right kind of stem cells to aid restorative repair and growth. Today, immense research is being conducted to understand the types and functions of each kind of stem cell and their allied application in medicine. Stem cell research conducted in India is making the process of understanding cord blood and stem cell utility in finding cures much easier, faster and affordable. Writes Sanjay Mittal in the report 'Stem Cell Research: The India Perspective', “Given India's science, tax regimes, regulation, supporting industries and financial markets are at a different stage of evolution to that of the developed economies, India faces unique challenges in the fluid arena of stem cell globalisation." In the same report, Mittal adds that "emerging economies like India are introducing policies designed to improve their global competitive position in this field." Most stem cell research in India is driven by and encouraged by private cord blood banks, which have the lion's share of the market in the country.

\section{Disadvantages of Stem Cell}

1. One of the major disadvantages of getting stem cells and umbilical cord preserved is that the banked cord blood may not be useful for all kinds of treatments. For example, if your child gets sick, then there is no 
assurance that the banked blood or cells would be of use for that particular sickness.

2. If a child develops any kind of a genetic disease, then his/her frozen blood may not be able to help him get cured. The cord blood too will have some genetic flaws which would have resulted in the disease in the first place and hence it won't prove to be a good treatment.

3. In many cases of illnesses and diseases, the introduction of a new set of immune cells from a donor may be more effective than using your blood and may be able to fight certain types of cancers. This too is a disadvantage of stem cell and cord banking.

4. Cord blood can mostly be used in the treatment of children only since the blood or cells taken from the cord is just about 3 to 5 ounces which is not enough to treat an adult and hence is a drawback.

5. Most blood banks claim that the stem cells taken will help siblings in case of any diseases but the possibility of this is just about $25 \%$ which is not enough in most cases. This is another drawback of stem cell banking.

6. There is a high possibility that the stored stem cells and blood may not come to any use at all. In this case, the large amount spent to preserve these may just go to waste. While it is true that banking of stem cells and cord blood is a matter of precaution but there is no definite guarantee that it may prove to be of use even once.

7. Another major disadvantage related to this method or practice is that it is very expensive and not affordable for most parents. Parenting is already an expensive affair, and most families may not be able to invest in something which is still new and comes with little guarantee of curing all kinds of diseases and illnesses. It won't be wrong to state that stem cell banking is currently limited. ${ }^{8}$

\section{Rationale}

Globally there are almost 20 lakh stem cell centres, whereas in India we don't have such a good network of stem cell registries. There are hardly 2-3 big networks of stem cells. When we are doing an allogeneic transplant, and if you don't have a sibling then you need to have an unrelated donor transplant and that is where we are having a problem as our present registry is not able to meet this demand. The current need is awareness of a stem cell registry. The Indian Council of Medical Research (ICMR) study says that if we have 10 lakh stem registry with us, we will be able to serve at least $40 \%$ of the demand, but when we have 20 lakh of the global registry then we are not able to meet the demand because of genetic variation. We need to spread awareness from various levels like NGO's, government, health sectors and everybody should take the initiative of doing this. People asking for stem cell banking will put pressure on authorities to put a stem cell registry system into action.

\section{Objectives}

- To assess knowledge and awareness of stem cells among eligible beneficiaries (ANC mothers and eligible couples).

- To provide knowledge to beneficiaries on the applications and availability so it leads to increase in acceptability by people.

\section{METHODS}

An interventional study was done in the Gwalior region for 2 months. A total of 100 eligible beneficiaries (ANC mothers and eligible couples) were registered for the study based on purposive sampling. All the willing beneficiaries were included in the study after informed consent; those who could not be followed up after 15 days of educational intervention were excluded from the study. Ethical permission was asked from the institute. A pretested structured questionnaire was used to assess the preintervention knowledge level of the study participants. An education intervention was planned, and all the beneficiaries were made aware of all aspects of stem cells. After 15 days of the education intervention, a post-intervention assessment was done with the same questionnaire as pre-intervention.

\section{Statistical Analysis}

Descriptive analysis was done in terms of percentages. To see the association between categorical variables, chi-square test was applied. A P-value less than 0.05 was considered statistically significant.

\section{RESULTS}

$28 \%(28 / 100)$ of total subjects in our study had heard about stem cells and among them, $85.7 \%(24 / 28)$ had heard about stem cell banking. Among the $85.7 \%(24 / 28)$ of the subjects, those who knew the source of information related to stem cell banking were maximum from media. Among $28 \%$ (28/100) of the subjects, $75 \%(21 / 28)$ were aware that stem cells were potentially beneficial and $25 \%(7 / 28)$ were unaware of the stem cells being potentially beneficial. After awareness, $100 \%$ of subjects considered that stem cells were beneficial.

$78.5 \%(22 / 28)$ of the subjects knew about the source of stem cell collection among the people knowing about stem cell banking. The umbilical cord as a source was known to all of them. After awareness, there was an increase in knowledge regarding the source of stem cells. Now $96 \%$ knew about the umbilical cord, $53 \%$ about peripheral blood, $18 \%$ about adipose tissue, $71 \%$ about embryo cells and $63 \%$ about amniotic fluid. Among the subjects who knew about stem cell banking, percentage of people knowing about the type of banks for stem cell storage, $32.14 \%(9 / 24)$ knew about the private banks, $3.57 \%(1 / 24)$ knew about the public banks and $32.14 \%(9 / 24)$ knew about both the banks.

Post awareness among our 100 subjects, $14 \%(14 / 100)$ knew about private banks, $3 \%$ (3/100) knew about public banks and $83 \%(83 / 100)$ about both the banks. Among our 100 subjects, the percentage of people satisfied with the price of stem cell banking was $36 \%$. Only $6 \%$ of the total subjects knew about other people whose stem cells had been stored. After awareness, no. of people knowing any of the diseases that could be cured through stem cells had increased that is $21 \%$ of the subjects knew less than 2 diseases and $79 \%$ of the subjects knew more than 2 diseases. After awareness, 86 $\%$ of the subjects thought that the regenerated tissues from stem cell were good enough to replace the previous tissues. 
In our study, subjects suggested that the means of spreading the awareness regarding the stem cells should be maximum through advertisement. After understanding the scenario, $85 \%$ of the subjects were optimistic about stem cell banking in future. $91 \%$ of the subjects were willing to donate stem cells after awareness.

After applying the chi-square test, the following results found out are mentioned under the table.

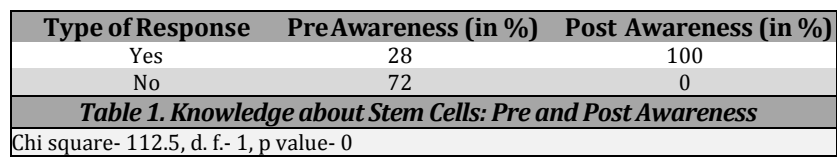

\begin{tabular}{|ccc|}
\hline Type of Responses & Pre Awareness (in \%) & Post Awareness (in \%) \\
\hline 1. Yes (<2 Diseases) & 15 & 21 \\
2. Yes (>2 Diseases) & 6 & 79 \\
No & 79 & 0 \\
\hline \multicolumn{2}{|c|}{ Table 2. No. of People Having Knowledge of Any of Disease That Can Be } \\
Cured via Stem Cells \\
\hline \multicolumn{2}{|c|}{ Chi square- 130.57, d. f.- 1, p value- 0 } \\
\hline
\end{tabular}

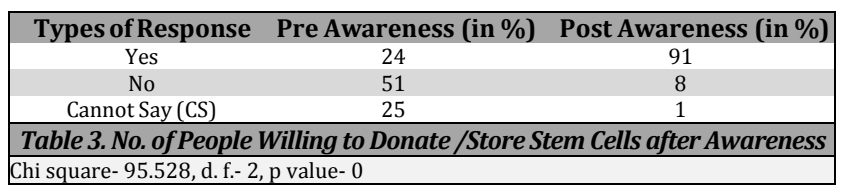

\section{DISCUSSION}

Stem cells are pluripotential cells having self-renewal, multilineage differentiation capacity and clonogenic efficiency. Umbilical cord blood at the time of delivery is a rich source of stem cells. It can be banked for future use. It is the best gift that the parents can offer to their children. Bone marrow, neural tissue, skin and retina are the other sources of stem cells. Dental pulp can be a source of stem cells. Deciduous teeth which exfoliate and wisdom teeth can be potential sources of stem cells. Dental caries and periodontal disease majorly contribute to tooth loss. At present, lost teeth are replaced with artificial removable or fixed prostheses. Stem cells offer the hope of regenerating the tooth. Tooth mortality is a public health problem in the urban and rural populations. We included samples from Gwalior city which is a district headquarter. The intention was to compare the knowledge and awareness regarding stem cells among the civilians of Gwalior city. The rural population was not included because our unsystematic observation revealed that more than 90-95 $\%$ of them had not even heard about the term stem cells. In the current study, $28 \%$ of subjects from Gwalior city had heard about stem cells and as compared to study conducted in Delhi by Mayank Kumar Saran, Nagesh Lakshminarayan, Manish Kumar and G. Shanmukha, $25 \%$ of subjects from Delhi had heard about stem cells. This difference is not quite significant because subjects from both the studies belonged to the urban population.

Comparing it to a study conducted in Bareilly city where the awareness was $18.3 \%$. This is because Delhi and Gwalior are large urban cities with high literacy rates. Exposure to media having a varied background and better socio-economic status in our study, majority of subjects had not heard about stem cells unlike in the study of GOOMER et al. where $62 \%$ of subjects had heard about stem cells. This difference maybe because it is a recent advancing field in India and also due to the less participation of media and other sources in spreading information regarding stem cells. In our study, media was the source of information for $42.4 \%$ of individuals similar to the study conducted in Delhi where the results found were $40 \%$. This was followed by doctors and health workers in both the studies. In our study, we found that $22 \%$ of subjects knew about the sources of stem cell collection among which the umbilical cord was the major source. Around $50 \%$ had an idea about stem cell banking cost among $28 \%$ of subjects who were aware of stem cells, as compared to a study conducted in Delhi where $55 \%$ of individuals had an idea about the cost of stem cell banking among $25 \%$ of individuals who were aware of stem cells.

A minority of subjects were aware of at least one benefit of stem cell banking although this knowledge was found to be higher among the citizens of Delhi. Among the people who were aware of stem cells, 9 subjects knew only about private banks and only 1 out of 100 knew about public banks and 9 knew about both as compared to the study in Delhi where knowledge about stem cell banking was higher. After a session of awareness, the number of people willing to donate stem cells was comparatively much higher in both the studies as compared to pre-awareness where the statistics were quite low.

The study throws light on the less than desirable knowledge (knowledge deficit) in the subjects who claimed to have heard about stem cells and knew about stem cells. It is high time that the message needs to be passed for the benefit of the larger population and the greater good.

\section{CONCLUSIONS}

Earlier the subjects were aware of the umbilical cord as a major source of collecting stem cells but now after conducting a session of awareness, the knowledge of the subjects regarding the source of stem cell collection had been considerably increased. Knowledge of subjects about the diseases that can be cured by stem cells has also been considerably increased.

Maximum people are not satisfied with the cost of stem cell storage, so there is a need to reduce the cost of it, so that maximum number of people take interest. Immoral issues regarding stem cell banking and transplantation have been elicited and change in thinking is seen in the majority of subjects. This shows that there is an urgent need to spread more awareness. Governments should actively participate in spreading information regarding public banks so that banking can be made easier for common people. We found that although media is a major source of information for the study subjects, it is not much effective in convincing them.

This shows that doctors and health workers can be potential sources of information for these subjects because of effective convincing strategies.

Although in spite of the presence of both public and private banks around, people are unaware of this, due to negligence by media and health workers.

Media and health workers should readily participate in spreading information taking people's interests into account. 


\section{Recommendations}

- A study with a larger sample is needed.

- Bringing stem cell topics in school would be of great help.

- Local political leaders can create much awareness.

- More doctors need to create awareness about stem cell banking.

- Governments can bring this into a health insurance policy for people in high-risk groups of certain diseases.

- Media and health workers should readily participate in spreading information taking people's interests into account.

Data sharing statement provided by the authors is available with the full text of this article at jemds.com.

Financial or other competing interests: None.

Disclosure forms provided by the authors are available with the full text of this article at jemds.com.

\section{REFERENCES}

[1] Pandey D, Kaur S, Kamath A, et al. Banking umbilical cord blood (UCB) stem cells: awareness, attitude and expectations of potential donors from one of the largest potential repository (India). PLoS One 2016;11(5);e0155782.

[2] Saran MK, Lakshminarayan N, Kumar M, et al. Knowledge and awareness of stem cells among expectant mothers and parents of elementary school children in Bareilly and Delhi cities. JIAPHD 2015;13(4);502-8.

[3] Bjuresten K, Hovatta O. Donation of embryos for stem cell research--how many couples consent? Human Reproduction 2003;18(6):1353-5.

[4] https://www.cryo-cell.com/cord-blood/private-vspublic-banking

[5] A study of cryo stemcell banking in Mumbai awareness andacceptance by customer in cryo stemcell (k) pvt ltd Mumbai. /https:// www.slideshare.net/abhijit055/

[6] Frati P, Gulino M, Pacchiarotti A, et al. A survey of Italian Physicians' opinion about stem cells research: what doctors prefer and what the law requires. Biomed Res Int 2014;2014:480304.

[7] https://www.lifecell.in/blog/what-are-diseases-treatedstem-cells

[8] http://icmr.nic.in/guidelines/Guidelines_for_stem_cell_r esearch_2017 